\title{
Peningkatan Nutrisi Tanaman Serealia Menggunakan Actinobacteria Endofit
}

\author{
Kartika Sari \\ Program Studi Pendidikan Biologi, FKIP, Universitas Muhammadiyah Metro, Lampung \\ e-mail: tikke_1812@yahoo.com
}

\begin{abstract}
Nutrient Enhancement In Cereal Crops Using Actinobacterial Endophytes

Wheat high demand without sufficient production and Actinobacterial endophytes usage limitation in Indonesia motivated this research. The aim was to determine Actinobacterial endophytes effect on nutrient enhancement in wheat (Triticum aestivum L.). It was hypothesized that they can enhance wheat nutrient. The experiment stages were: 1) Pot-Trial I, confirming nutrient enhancement using Actinobacteria in 6 soil types; 2) Pot-Trial II, screening Actinobacteria strains; and 3) Field-Trial. The results showed that Actinobacteria effects varied for different nutrients and site based differences. In Pot-Trial I, different soil types significantly affected the manganese and zinc content $(\mathrm{P}=0.00$ and $\mathrm{P}=0.01)$, but not inoculation of Actinobacteria nor the combination of them. Field Trials showed the same trends. Combination between those treatments significantly affected manganese content $(\mathrm{P}=0.045)$. Nutrient analysis on xylem sap in Pot Trials 2 only showed the value differences since there was insufficient collected volume to be statistically analyzed. Zinc and iron contents were the highest in Actinobacteria EUM165 treatment and the highest manganese content in Actinobacteria EN16. In conclusion, wheat nutrient content is affected by Actinobacteria and different soil types but there was insufficient evidence to generally conclude that it can be enhanced. They have their own effects and affected each other in enhancing nutrient content.
\end{abstract}

Keywords: Nutreint, wheat, endophytic Actinobacteria

\begin{abstract}
ABSTRAK
Tingginya permintaan gandum tidak disertai produksi yang cukup, serta terbatasnya pemanfaatan Actinobacteria endofit di Indonesia, melatarbelakangi penelitian ini. Tujuannya untuk mengetahui pengaruh penambahan Actinobacteria endofit terhadap nutrisi gandum (Triticum aestivum L.). Diduga, penambahan Actinobacteria endofit dapat meningkatkan kandungan nutrisinya. Tahapan penelitian meliputi: 1) Uji-Pot I, mengonfirmasi peningkatan nutrisi gandum menggunakan Actinobacteria pada 6 jenis tanah; 2) Uji-Pot II, menguji berbagai strain Actinobacteria terhadap peningkatan nutrisi gandum; serta 3) Uji Lapangan. Hasilnya menunjukkan bahwa Actinobacteria meningkatkan nutrisi gandum secara berbeda tergantung nutrisi yang diuji serta jenis tanah yang digunakan. Pada Uji-Pot I, jenis tanah berpengaruh nyata terhadap kandungan mangan dan seng $(\mathrm{P}=0.00$ dan $\mathrm{P}=0.01)$, tapi pemberian Actinobacteria maupun kombinasi keduanya tidak. Uji Lapangan menunjukkan hasil yang sama. Kombinasi kedua perlakuan meningkatkan kandungan mangan secara signifikan ( $\mathrm{P}=0.045)$. Analisis cairan xilem dari Uji-Pot II menunjukkan perbedaan hasil tanpa uji statistik karena terbatasnya cairan yang dikumpulkan. Kandungan tertinggi seng dan zat besi ditunjukkan oleh perlakuan Actinobacteria EUM165 dan mangan yang lebih tinggi oleh Actinobacteria EN16. Disimpulkan bahwa kandungan nutrisi tanaman gandum dapat dipengaruhi oleh pemberian Actinobacteria endofit serta perbedaan jenis tanah, namun tidak cukup bukti untuk menyimpulkannya secara umum. Baik jenis tanah maupun Actinobacteria endofit memiliki pengaruh sendiri serta saling mempengaruhi terhadap kandungan nutrisi tanaman gandum.
\end{abstract}

Kata kunci: Nutrisi, gandum, actinobacteria endofit 


\section{PENDAHULUAN}

Tanaman gandum (Triticum aestivum) adalah salah satu tanaman serealia yang penting, karena menjadi makanan pokok di beberapa negara. Pada dasarnya tanaman gandum dapat ditanam di berbagai tempat, karena mudah beradaptasi. Menurut Curtis et al. (2002) diperkirakan hal tersebut dikarenakan kompleks genomnya bersifat plastis.

Walaupun gandum umum ditanam di beberapa negara, tanaman ini belum cukup lazim untuk ditanam di Indonesia. Kondisi tanah dan cuaca kurang mendukung pertumbuhan gandum. Namun begitu, bukan berarti permintaan akan gandum di Indonesia rendah. Kenyataannya, permintaannya makin tinggi setiap tahun. Konsumsi per kapita telah meningkat dari $8,1 \mathrm{~kg}$ pada tahun 1980 menjadi 21,2 kg pada tahun 2010 . Angka ini diperkirakan akan meningkat setiap tahun (Weigand, 2011). Perubahan konsumsi dari beras ke gandum disebabkan oleh peningkatan pendapatan serta urbanisasi di Indonesia (Fabiosa, 2006). Saat ini Indonesia masih bergantung pada impor untuk memenuhi permintaan ini.

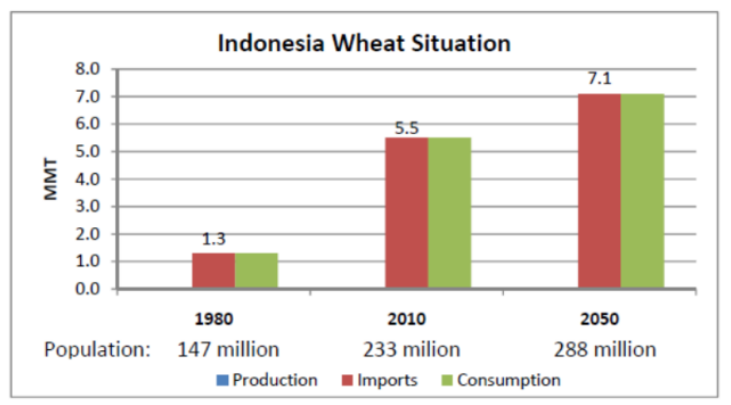

Gambar 1. Kondisi Gandum di Indonesia (MMT: Million Metric Tons)

(Weigand, 2011)

Sejauh ini yang melakukan penelitian secara intensif terhadap gandum adalah BATAN. Penelitian dilakukan untuk menghasilkan varian gandum yang cocok di Indonesia, dan telah dihasilkan dua varietas yang dapat beradaptasi dan masih terus melanjutkan penelitian terhadap adaptasi tanaman gandum pada dataran rendah (Soeranto \& Dameria, 1995).

Sebagai makanan pokok, sangat penting untuk meningkatkan kandungan gizi di dalamnya. Secara teoritis, hal tersebut dapat dilakukan melalui peningkatan mikronutrisi pada bulir-bulir gandum (Frossard et al., 2000). Beberapa mikroorganisme sangat efektif dalam mengatasi masalah pertanian, termasuk meningkatkan penyerapan nutrisi pada tanah yang kekurangan nutrisi tertentu. Pada beberapa jenis tanah, nutrisi-nutrisi tertentu tidak dalam kondisi tersedia bagi tanaman.

Salah satu jenis mikroorganisme yang berpotensi untuk membantu penyerapan nutrisi tanaman adalah Actinobacteria endofit. Actinobacteria adalah bakteri gram positif yang dapat membentuk hifa dan miselia, dapat ditemukan di dalam jaringan tanaman sehat, dan tidak menimbulkan penyakit bagi tanaman. Penelitian sebelumnya menunjukkan bahwa organisme ini dapat memperpanjang batang gandum secara signifikan serta meningkatkan massa akar (Coombs, 2001). Selain itu, Actinobacteria endofit juga dapat berfungsi sebagai perlindungan tanaman dengan cara mengembangkan suatu mekanisme non spesifik, menghasilkan substans anti mikroba yang membantu tanaman dalam melawan pathogen (Berg \& Hallman, 2006).

Untuk itu dikembangkanlah suatu penelitian untuk mengetahui pengaruh penambahan Actinobacteria endofit terhadap peningkatan nutrisi tanaman gandum.

\section{METODE}

Penelitian ini mencakup tiga tahapan, yakni Uji-Pot 1, Uji-Pot 2, serta Uji Lapangan.

\section{A. Uji-Pot 1}

Uji ini bertujuan untuk mengkonfirmasi peningkatan nutrisi tanaman gandum menggunakan Actinobacteria endofit pada 6 macam tanah. Tanah yang digunakan diambil dari beberapa ladang pertanian di Australia, yakni: Avon, Roseworthy, Pinnaroo, Sandilands, Turretfield, dan Waikerie. Sampel tanah dikeringanginkan terlebih dahulu. Biji yang digunakan adalah biji gandum varietas Yitpi, yang dibalut terlebih dahulu dengan spora Actinobacteria endofit yang telah dikultur sebelumnya. Biji yang telah dibalut spora tersebut ditanam dalam pot, dan di atas permukaan tanahnya ditutupi dengan bijih plastik putih untuk mengurangi percikan tanah selama penyiraman. Setelah tumbuh tunas, larutan Hoagland diberi setiap dua minggu sekali sampai dengan minggu ke-7. Penyiraman dihentikan saat tanaman gandum mulai berbulir. Tanaman gandum ditanam di rumah kaca sampai siap panen pada minggu ke-15. Bulir gandum dipanen, dikeringkan, dikupas, lalu digiling. Sampel lalu 
dianalisis di CSBP Soil and Plant Analysis Laboratory, Australia Barat.

\section{B. Uji-Pot 2}

Eksperimen ini bertujuan untuk memilih Actinobacteria endofit strain mana saja yang dapat menigkatkan nutrisi tanaman gandum. Biji gandum dibalut dengan beberapa jenis strain yang berbeda yakni: EN16, EN27, PIP76, PIP204, EUC75, EUC76, BD29, BD133, EUM135, EUM 165, FW11, CAP28, CAP 189, CAP214, HCA1052, HCA1141, HCA1167, HCA1262, HCA1290, dan HCA1297. Biji-biji tersebut lalu ditanam dalam pot yang berisi tanah Avon, dipelihara di rumah kaca sampai dengan minggu ke-4. Setelah tumbuh tunas, larutan Hoagland diberikan. Setelah berusia 4 minggu, cairan xylem dikumpulkan dari tanaman-tanaman tersebut dengan menggunakan metode destruktif. Sampel cairan xylem kemudian dianalisis kandungan nutrisinya di Waite Analytical Service, Glen Osmond, Australia Selatan.

\section{Uji Lapangan}

Biji gandum yang dibalut dengan Actinobacteria endofit ditanam di tiga lahan berbeda, yakni: Sandilands, Waikerie, dan Pinnaro. Tanaman gandum yang belum berbulir dipanen, dikeringkan, lalu daunnya digiling. Sampel dianalisis di CSBP Soil and Plant Analysis Laboratory, Australia Barat.

\section{HASIL DAN PEMBAHASAN}

Dari rangkaian eksperimen yang dilakukan, diperoleh hasil-hasil sebagaimana dijelaskan berikut:

\section{A. Uji-Pot 1}

Hasil panen setelah penanaman selama 15 minggu menunjukkan hasil berat kering bulir gandum sebagai berikut:

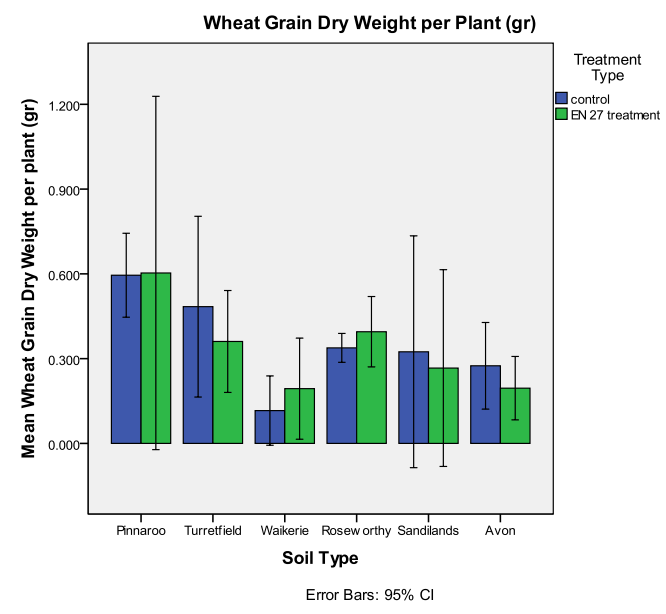

Gambar 2. Berat Kering Bulir Gandum. Tanaman gandum dibalut dengan Actinobacteria endofit, ditanam selama 15 minggu. Jika batang error Interval Konfidensial 95\% tidak tumpang tindih, berarti terdapat perbedaan yang signifikan $(\mathrm{P}<0,05)$

Salah satu cara yang sering digunakan untuk mengukur pertumbuhan adalah berat kering atau berat segar, karena hasil interaksi dari komunitas tanaman diukur sebagai rasio variable tampilan, biasanya berupa biomassa (Goldberg et al., 1999). Gambar 2 di atas menunjukkan peningkatan pertumbuhan, yang nampak melalui berat kering bulir gandum. Terlihat bahwa hanya tanaman gandum yang ditanam di tanah Waikerie, Roseworthy, dan Avon yang memberikan hasil yang yang lebih baik saat dibalut dengan Actinobacteria endofit, namun tidak secara signifikan. Gandum di tanah Pinnaroo menunjukkan hasil yang paling baik dengan maupun tanpa dibalut Actinobacteria endofit. Fenomena ini dijelaskan oleh Coombs (2001) yang menyatakan bahwa Actinobacteria endofit berperan penting dalam pertumbuhan tanaman dengan cara menyalurkan nutrisi ke tanaman secara lebih efisien.

Berdasarkan hasil analisis berat kering tersebut, maka analisis nutrisi hasil panen hanya dilakukan pada sampel yang berasal dari empat macam tanah, yakni: Avon, Waikerie, Pinnaroo, dan Roseworthy. Hasilnya terlihat dari grafik di bawah ini:

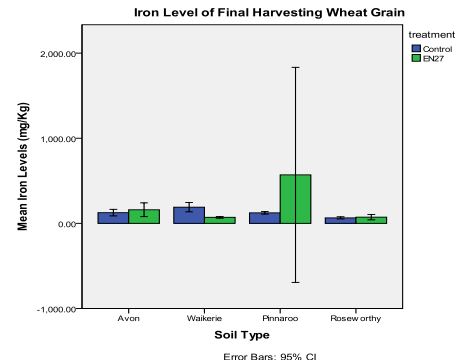

(a)

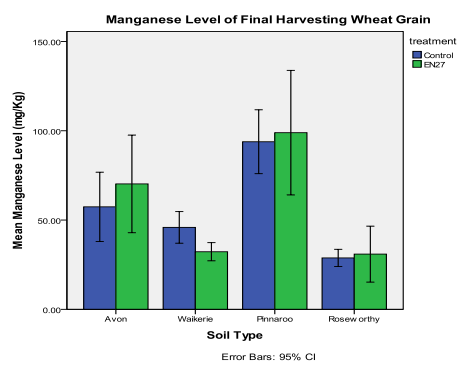

(b) 


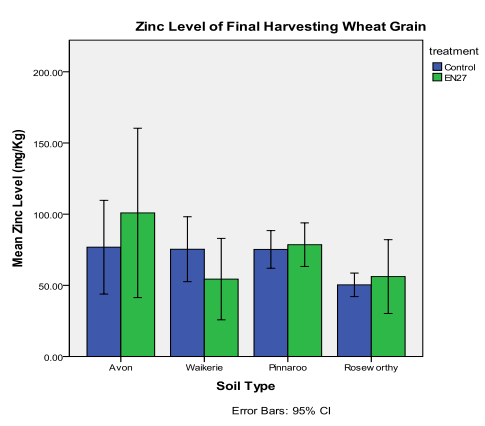

(c)

Gambar 3. Kandungan Nutrisi Bulir Gandum. Analisis (a) zat besi (mg/kg); (b) mangan (mg/kg) ;(c) seng (mg/kg); dilakukan setelah gandum diberi perlakuan Actinobacteria endofit pada beberapa macam tanah selama 15 minggu. Jika batang error Interval Konfidensial $95 \%$ tidak tumpang tindih, berarti terdapat perbedaan yang signifikan $(\mathrm{P}<0,05)$.

Dari Gambar 3 tersebut terlihat bahwa pada gandum yang ditanam di tanah Avon dan Roseworthy, kandungan zat besi, mangan, maupun seng lebih tinggi pada perlakuan yang diberi Actinobacteria endofit, walaupun tidak secara signifikan. Terlihat juga bahwa kandungan zat besi pada gandum dari tanah Pinnaroo sangat tinggi, namun hanya terlihat dari satu ulangan saja, sehingga disimpulkan terdapat kemungkinan kontaminasi pada ulangan ini.

Pada penelitian sebelumnya, penambahan Actinobacteria endofit berpotensi untuk meningkatkan kandungan nutrisi pada tanaman, seperti zat besi dan seng (Çamakçi et al. 2006). Sementara itu, beberapa nutrisi, seperti zat besi dan seng, tidak dalam kondisi tersedia bagi tanaman, sehingga dapat membatasi pertumbuhan dan produksi tanaman. Hal ini tidak dapat diselesaikan hanya dengan menambahkan pupuk yang mengandung zat besi, karena masalahnya bukanlah pada kandungannya, melainkan bentuk ketersediaannya (Guerinot 2010). Dalam tanah, seng dapat berupa zat yang larut lair, seng yang dapat dipertukarkan, atau justru tidak larut. Akibatnya, tidak selalu mudah untuk menyerap seng dari tanah (Broadley et al. 2007).

Nakouti dan Hobbs (2012) menjelaskan bahwa kehadiran Actinobacteria dapat mengatasi masalah ini, karena mikroorganisme ini dapat memproduksi siderophore secara ekstraselular, yakni komponen yang mampu mengikat zat besi dengan lebih baik. Hasilnya, mikroorganisme ini memungkinkan tanaman untuk memperolah ion- ion walaupun tanah dalam kondisi kekurangan elemen tersebut. Dengan demikian, penyerapan zat besi maupun seng dapat diperbaiki sehingga kandungan undur hara tersebut di dalam tanaman dapat ditingkatkan.

Pada penelitian kali ini, walaupun penambahan Actinobacteria endofit tampak meningkatkan beberapa kandungan nutrisi, hasil yang diperoleh tidaklah signifikan secara statistik. Kemungkinan yang terjadi adalah perlakuan tersebut dipengaruhi oleh perlakuan lainnya, yakni macam tanah yang digunakan. Untuk itu, tanah yang digunakan juga dianalisis kandungannya, sebagaimana yang ditampilkan pada tabel berikut:

Tabel 1. Hasil Analisis Tanah

\begin{tabular}{|l|l|l|l|l|l|}
\hline \multicolumn{1}{|c|}{ Tanah } & $\mathrm{pH}$ & $\begin{array}{c}\text { DTPA } \\
\text { Besi } \\
\mathrm{mg} / \mathrm{Kg}\end{array}$ & $\begin{array}{c}\text { DTPA } \\
\text { Mangan } \\
\mathbf{m g} / \mathrm{Kg}\end{array}$ & $\begin{array}{c}\text { DTPA } \\
\text { Seng } \\
\mathrm{mg} / \mathrm{Kg}\end{array}$ & \multicolumn{1}{|c|}{ Tekstur } \\
\hline Waikerie & 7,6 & 3,77 & 4,47 & 0,61 & $\begin{array}{l}\text { Lempung } \\
\text { berpasir }\end{array}$ \\
\hline Sandilands & 6,9 & 17,42 & 2,78 & 3,65 & $\begin{array}{l}\text { Lempung } \\
\text { berpasir }\end{array}$ \\
\hline Pinnaroo & 5,4 & 21,12 & 6,1 & 3,72 & Lempung \\
\hline Avon & 7,9 & 10,66 & 3,64 & 1,07 & Liat \\
\hline Roseworthy & 7,6 & 9,45 & 2,79 & 1,81 & $\begin{array}{l}\text { Liat } \\
\text { berlempung }\end{array}$ \\
\hline Turretfield & 7,5 & 11,01 & 6,54 & 0,92 & $\begin{array}{l}\text { Liat } \\
\text { berlempung }\end{array}$ \\
& & & & & \\
\hline
\end{tabular}

Terlihat bahwa macam tanah yang digunakan memberikan efek berbeda terhadap kandungan nutrisi tanaman gandum. Macam tanah secara signifikan mempengaruhi berat kering bulir gandum sebagaimana terlihat pada Gambar 2. Frossard et al., (2000) menyatakan bahwa setiap tanah memiliki karakter, fungsi psikokimia, serta property biologi masing-masing yang dapat mempengaruhi penyerapan nutrisi oleh tanaman.

\section{B. Uji-Pot 2}

Pada tahap ini, jumlah cairan xilem yang berhasil dikumpulkan kurang maksimal, sehingga tidak dapat dianalisis secara statistik. Namun, secara umum diperoleh data sebagai berikut: 


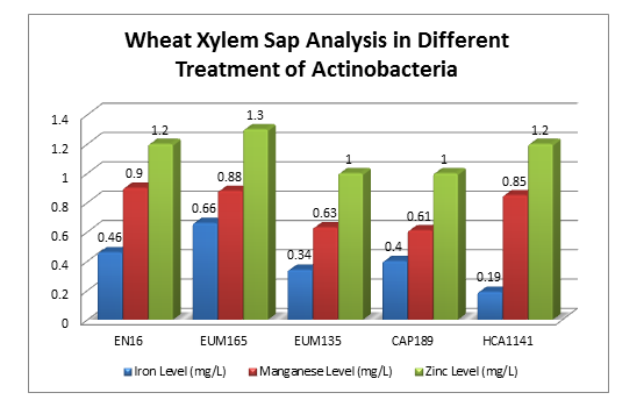

Gambar 4. Analisis Cairan Xilem Gandum

Serupa dengan darah, cairan xilem mengandung banyak informasi dari berbagai sel dan organ tanaman mengenai kondisi umum tanaman tersebut. Cairan xilem juga berperan dalam penyerapan air dan nutrisi pada tanaman, sehingga kualitas cairan xilem dapat mempengaruhi pertumbuhan tanaman (Schurr, 1998). Walaupun tidak didukung oleh analisis statistik, saat membandingkan lima sampel yang berhasil dikumpulkan, cairan xilem dari gandum yang dibalut dengan Actinobacteria strain EUM165 menunjukkan kandungan zat besi dan seng yang paling tinggi. Sedangkan kandungan mangan terbaik terdapat pada cairan xilem gandum yang diberi perlakuan Actinobacteria strain EN16. Diduga hal ini disebabkan oleh kemampuan kedua strain tersebut untuk memproduksi siderophore lebih baik dari strain lainnya.

\section{UJI LAPANGAN}

Dari Uji Lapangan yang dilakukan, diperoleh hasil sebagai berikut:

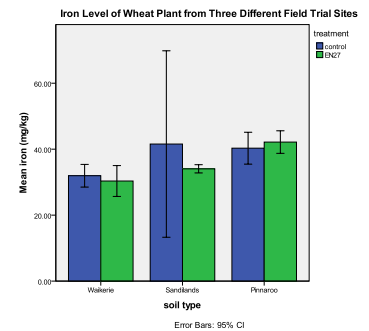

(a)

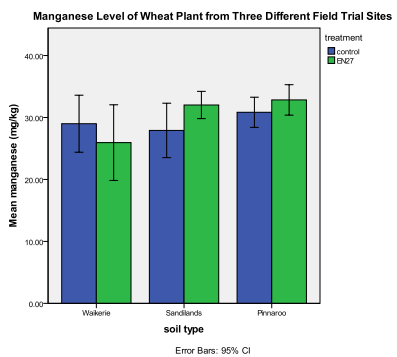

(b)

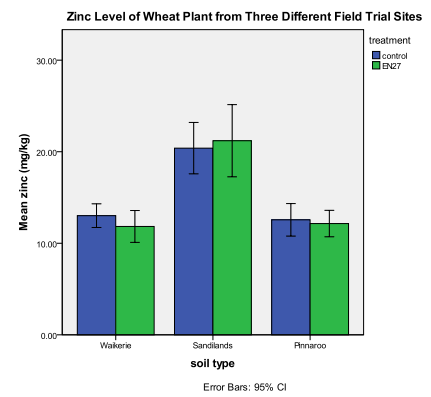

(c)

Gambar 5. Kandungan Nutrisi Tanaman Gandum. Analisis (a)zat besi (mg/kg);(b)mangan $(\mathrm{mg} / \mathrm{kg}) ;(\mathrm{c}) \quad$ seng $(\mathrm{mg} / \mathrm{kg}) ; \quad$ daun tanaman gandum dilakukan setelah diberi perlakuan Actinobacteria endofit dan ditanam pada tiga lahan yang berbeda. Jika batang error Interval Konfidensial 95\% tidak tumpang tindih, berarti terdapat perbedaan yang signifikan $(\mathrm{P}<0,05)$

Dari Gambar 5 tersebut tampak bahwa secara umum pemberian Actinobacteria endofit tidak memberikan pengaruh yang signifikan terhadap peningkatan nutrisi pada tanaman gandum. Hal ini menunjukkan kecenderungan yang sama dengan apa yang dihasilkan pada UjiPot 1. Walaupun demikian, dari hasil analisis statistik terlihat bahwa macam tanah memberikan pengaruh yang nyata, di mana tanah Pinnaroo dan Waikerie meningkatkan kandungan zat besi dan mangan pada tanaman gandum. Kombinasi antara macam tanah dengan pemberian Actinobacteria hanya berpengaruh nyata pada kandungan mangan $(P=0,045)$. Dari sana terlihat bahwa perlakuan yang ada saling mempengaruhi satu sama lain. Tanah yang berbeda dapat mempengaruhi pemberian Actinobacteria terhadap peningkatan nutrisi tanaman. Karakter tanah yang ada sebagaimana terlihat pada Tabel 1 diduga membatasi kemampuan Actinobacteria untuk berkembang sehingga menurunkan kemampuan mereka untuk membantu penyerapan nutrisi, baik itu tekstur tanahnya, $\mathrm{pH}$ tanahnya, maupun kombinasi keduanya. Gregory et al., (1992) menjelaskan bahwa lapisan lempung pada tanah dapat menghalangi pertumbuhan akar dan kemampuan tanaman dalam dalam menyerap air dan nutrisi. Cunningham \& Kuiack (1992) menambahkan bahwa Actinobacteria membutuhkan kondisi yang sedikit basa untuk tumbuh dengan baik, dan dapat terhambat pada kondisi $\mathrm{pH}$ yang terlalu rendah. 


\section{SIMPULAN}

Sebagai makanan pokok yang makin tinggi konsumsinya, sangat penting untuk meningkatkan potensi kandungan nutrisinya. Actinobacteria endofit digunakan karena memiliki kemampuan untuk memperbaiki performa tanaman sekaligus melindunginya. Setelah diberi perlakuan, dapat disimpulkan bahwa aplikasi Actinobacteria pada tanaman gandum memberikan pengaruh yang bervariasi, dipengaruhi oleh macam tanahnya. Penambahan Actinobacteria ternyata hanya mampu meningkatkan kadar nutrisi secara nonsignifikan, namun macam tanah yang berbeda memberikan hasil yang signifikan terhadap nutrisi tanaman. Sedangkan kombinasi keduanya hanya mampu meningkatkan kandungan mangan secara signifikan, namun tidak terhadap zat besi dan seng. Diperkirakan pengaruh karakteristik tanah mempengaruhi kemampuan Actinobacteria dalam meningkatkan nutrisi tanaman.

\section{UCAPAN TERIMA KASIH}

Ucapan terima kasih dihaturkan kepada Prof. Christopher M. Franco (Flinders University) dan Associate Prof. Gupta Vadakattu (CSIRO) atas sumbang sarannya serta kepada pihak DIKTI serta Universitas Muhammadiyah Metro atas kesempatan belajar serta penelitian yang diberikan.

\section{DAFTAR PUSTAKA}

Berg, G \& Hallman, J. 2006. Control of Plant Pathogenic Fungi with Bacterial Endophytes. Springer. Berlin.

Broadley, MR, White, PJ, Hammond, JP, Zelko, I \& Lux, A. 2007. Zinc in Plants. New Phytologist. Vol 173. No 4. Pp 677-702.

Çakmaçi, R, Donmez, F, Aydin, A \& Sahin, F. 2006. Growth Promotion of Plants by Plant-Growth-Promoting Rhizobacteria Under greenhouse and Two Different Field Soil Conditions. Soil Biology and Biochemistry. Vol 38. No 6. Pp 1482-1487.

Cunningham, JE \& Kuiack, C. 1992. Production of Citric and Oxalic Acid and Solubilization of Calcium Phosphate by Penicillium bilaii. Applied and Environmental Microbiology. Vol 58. No 5. Pp 1451-1458.

Curtis, BC, Rajaram, S \& Gomes, MH. 2002. Bread Wheat: Improvement and Production. FAO UN.
Coombs, JT. 2001. The Isolation and Characterization of Endophytic Actinomycetes from Wheat. Doctor of Phylosophy Thesis, Flinders University.

Fabiosa, JF. 2006. Westernization of Asian Diet: The Case of Rising Wheat Consumption in Indonesia. Iowa State University. Iowa.

Frossard, E, Bucher, M, Mächler, F, Mozafar, A \& Hurrel, R. 2000. Potential for Increasing The Content and Bioavailability of Fe, Zn and $\mathrm{Ca}$ in Plants for Human Nutrition. Journal of The Science and Food Agriculture. Vol 80. No 7. Pp 861-879.

Goldberg, DE, Rajaniemi, T, Gurevitch, J \& Stewart-Oaten, A. 1999. Empirical Approaches to Quantifying Interaction Intensity: Competition and Facilitation Along Productivity Gradients. Ecology. Vol 80. No 4. Pp 1118-1131.

Gregory, PJ, Tenat, D \& Belford, RK. 1992. Root and Shoot Growth, and Water and Light Use Efficiency of Barley and Wheat Crops Grown on a Shallow Duplex Soil in a Mediterranian-type Environment. Aust.J.Agric.Res. Vol 43. P 18.

Guerinot, M. 2010. Iron Cell Biology of Metals and Nutrients. In R Hell \& R-R Mendel (eds). Springer. Berlin. Vol 17. Pp 75-94.

Nakouti, I \& Hobbs, G. 2012. Characterization of Five Siderophore Producing Actinomycetes from Soil Samples and The Use of Antibiotic Resistance to Differentiate The Isolates. Int. J. Agr. Sci. Vol 4. Pp 44-51.

Schurr, u. 1998. Xylem Sap Sampling-New Approaches to An Old Topic. Trends in Plant Science. Vol 3. No 8. Pp 293-298.

Soeranto, H \& Dameria, H. 1995. Mutation Breeding in Wheat. FAO UN.

Weigand, C. 2011. Wheat Import Projections Towards 2050. US Wheat Association. 